\title{
Language-Building Activities and Interaction Variations With Mixed-Ability ESL University Learners in a Content-Based Course
}

\author{
Actividades de construcción de lengua y patrones de interacción \\ en estudiantes universitarios de inglés como segunda lengua con \\ habilidades desiguales dentro de un curso basado en contenidos ${ }^{*}$
}

\author{
Héctor Manuel Serna Dimas \\ hmserna@correo.ean.edu.co \\ Universidad EAN, Colombia \\ Erika Ruíz Castellanos \\ eruiz@fcf.com.co \\ Universidad del Rosario, Colombia
}

The preparation of both language-building activities and a variety of teacher/student interaction patterns increase both oral language participation and content learning in a course of manual therapy with mixed-language ability students. In this article, the researchers describe their collaboration in a content-based course in English with English as a second language learners. The data gathered through lesson plans, sociograms, and student feedback cards showed an increase of students' involvement in class activities since their concern was to be able to diagnose and treat their future patients' physical condition through a structured interview for which both careful language elaboration and therapist/patient interaction were essential.

Key words: Classroom interaction patterns, language-building activities, mixed-ability language students

La preparación de actividades de construcción de lengua y una variedad de patrones de interacción entre el profesor y los estudiantes incrementa tanto la participación oral como el aprendizaje de contenidos en un curso de terapia manual con estudiantes con habilidades lingüísticas desiguales. En este artículo los investigadores describen su colaboración en un curso de contenidos en inglés con estudiantes de inglés como segunda lengua. Los datos recolectados en planeaciones de clase, sociogramas y fichas de

* Received: January 16, 2014. Accepted: March 9, 2014. 
retroalimentación mostraron un incremento en los niveles de participación de los estudiantes en las actividades de clase debido a su preocupación por estar en capacidad de diagnosticar y tratar la condición física de sus pacientes a través de entrevistas estructuradas para las cuales era esencial tanto la elaboración de las preguntas como la interacción con los pacientes.

Palabras clave: actividades de construcción de lengua, estudiantes con habilidades lingüísticas desiguales, patrones de interacción en clase

\section{Introduction}

Universidad del Rosario is one of the oldest institutions of higher education in Colombia. The university has undergraduate and graduate programs in areas such as Medicine and Health Sciences, Law, Economics, International Business Management, Business Administration, Political Science, International Relations, Urban Development, Sociology, Anthropology, Journalism, History, Liberal Arts, Philosophy, Mathematics, and Biology.

The university has determined that one of the most important areas for its growth is internationalization, which is understood as the process of promoting university work in areas such as teaching, research, and community outreach in the international milieu. Thus, it is compulsory for the university programs in all schools and departments to offer content-based courses in English. That is, courses that belong to the universities' programs' curricula. However, professors in charge of these courses are often confronted with a series of challenges, such as having students with diverse linguistic abilities. This situation also poses issues for professors regarding the demands that both the content and the language will require of students in terms of their participation, classwork learning, and evaluation.

Two university professors in the areas of manual therapy and English language teaching decided to team up on an action-research study with students from the Physical Therapy program in the School of Medicine and Health Sciences. The researchers decided to combine their expertise so that they both could see how the manual therapy professor was engaging her students in content-based learning in English, and how the language professor was looking at the flow of language based upon both the manual therapy professor's input and the students' participation either individually or in groups.

The main concern that triggered this research project was the fact that the professor in manual therapy was not pleased with the idea of teaching again a course on manual therapy with English as a second language (ESL) learners who had demonstrated very little participation and interaction among themselves due to the barriers in their second language oral proficiency.

The purpose of this study is to describe how both the deliberate work in language-building activities and a variety of teacher/student interaction patterns such as 
individual, pair, and group work increase students' class participation and content learning in a manual therapy course with students of diverse language abilities in the Physical Therapy Program at Universidad del Rosario in Bogotá, Colombia.

We consider that there is a need to research content-based instruction in higher education because there is a growing interest among Colombian universities to work towards their internationalization. This process of internationalization has to do with having content courses taught in English and with promoting academic mobility. Many universities are running dual degree programs for which students need to find courses taught in English. Students who choose a dual degree program are not always fluent in the native language of the university that hosts the program. In fact, English works as an international language to help them make the corresponding matches in their curricula.

For the purpose of this research, we define language-building activities as the language considerations regarding vocabulary, grammar, and pragmatic elements required for students to engage in appropriate discourse interactions to match the course proceedings. Bean and Peterson (1998) established some classroom events that involved participation; some of these linguistic behaviors can be summarized as follows: discussion moments, short exchanges between professor and students, student comments made in class, students who take risks and make mistakes, students who ask questions for clarification, and students who ask questions in private or in small groups.

This article begins with a description of the specific context of this research followed by a theoretical framework which reviews some studies related to the teaching of students in tertiary education, particularly in the health sciences. In fact, some of the studies were conducted with ESL students in English speaking universities. The reviewed studies address both cognitive and language related aspects that are considered important in the education of professionals in the health sciences, particularly in the rehabilitation areas. This section also discusses some theoretical tenets from second language acquisition, cooperative learning, and differentiated learning. Then the study describes the research design, the data sources, instruments of data collection, and the researchers' intervention. The study ends with a discussion of the results, the limitations, and the conclusions.

\section{Context}

\section{Physical Therapy Program at Universidad del Rosario}

The Physical Therapy program is part of the rehabilitation sciences field in the School of Medicine and Health Sciences at Universidad del Rosario. The program, according to the Colombian legal framework (law 528, 1999), determines that its object of study is the human body movement as a central driving force of human development. The university program 
recognizes the human being as a subject that moves about in the world through social and cultural interrelations. From this perspective, not only does it delve into the structural, physical, and physiological domains of human movement but it also advances towards the understanding of the complexity of their relations in the contexts in which physical therapy operates (Universidad del Rosario, 2011).

\section{Manual Therapy}

Manual therapy is a specialized field in the basic formation for Physical Therapists, and it promotes the necessary knowledge of evaluation and intervention processes as concerns the purpose of therapeutic treatment options. This course gives students the basic elements necessary for the therapeutic approach to neuromusculoskeletal dysfunction from the perspective of manual therapy, and the opportunity to explore and develop second language skills. This specialized field also brings together a set of procedures that both promotes and improves hands perception and sensibility as a tool for handling body structures that are directly related to individuals with body movement limitations.

\section{Theoretical Framework}

There are not very many English for specific purposes (ESP) studies that address both the linguistic and cognitive needs of prospective professionals in rehabilitation programs such as occupational therapy, physical therapy, or speech pathology. In fact, there is scant research in the preparation of these professionals in either second or foreign language settings. Nevertheless, the research that was reviewed pays special attention to both the language and cognitive abilities that are required and, more importantly, expected from these professionals. Thus, studies on how both complex cognitive thinking and their related language abilities are relevant for areas such as the health sciences, language learning, and content-based instruction with ESL students.

Liu, Chang, Yang, and Sun (2001) developed a study with a group of university students that intended to determine a detailed examination of the group's needs in courses of English for either general (EGP), specific (ESP), or academic purposes (EAP). The researchers set out to "examine how much students' perceived needs conflicted with their wants and lacks regarding their enrollment in English courses" (p. 273). They developed a questionnaire to determine students' needs in EGP, ESP, or EAP courses, and the reasons for enrollment in either of these courses. The results indicated that students do not see that the language abilities taught in the courses had equal value. The results also indicated a mismatch between students' perceived needs and their course taking action.

The above study illustrates a common scenario with ESL learners, which is the fact that one of the main sources of conflict between instructors and students is the expectations about 
the language abilities of the latter. This mismatch usually has almost immediate side effects on the course's aims, objectives, contents, and evaluation.

Another aspect that requires special consideration in using English as the medium of instruction at university level is the quintessential question for the accountability of educational processes. University professors often express their concerns about students' achievement in courses taught in a language that is not their native language, especially if they are working in complex areas that deal with the treatment of patients and their physical health.

A study researching the faculty perspectives on the English language competence of nonnative English speakers was developed by Andrade (2010). She describes the population of international students recruited by a university in an English-speaking country. She also gives a detailed account of the university English requirements for these students in terms of their levels of proficiency through different tests such as the Test of English as a Foreign Language, TOEFL ${ }^{\circledR}$.

The purpose of her study was to obtain data from the university faculty in some areas of inquiry that the researcher established as:

(a) Estimation of students' language abilities, (b) impact of having L2 students in their classes, (c) faculty efforts to help students improve, (d) future possibilities for faculty support, (e) institutional efforts to help L2 students improve, and (f) future institutional possibilities. (Andrade, 2010, p. 225)

The study's findings indicated that professors viewed students' language abilities as adequate although they could be improved. Professors acknowledged the presence and efforts of their nonnative students without compromising their views on their achievement compared with that of native speakers. The findings regarding faculty efforts to support students indicated that the professors were more focused on maintaining the demands of their courses; they felt that other people in the university should provide this help directly to the students. Regarding institutional efforts, the faculty saw it was necessary for other university bodies to work with these students' particular needs. They also pointed out that these other possibilities should be offered as additional help in terms of mandatory work for these students.

The following study is not related to the education of ESL physical therapists, yet it provides relevant evidence on the development of clinical reasoning skills in the education of physical therapists. Moreover, the maturity of such skills is largely built around cognitive operations that are manifested mainly through language. Hendrick, Bond, Duncan, and Hale (2009) conducted an empirical study that intended to provide evidence regarding the conceptualizations of physical therapy students in the clinical reasoning that they demonstrated in musculoskeletal practice. 
The study was motivated by the musculoskeletal clinical professor's concerns about the variation of physical therapy students' clinical reasoning skills across the curriculum and throughout their education (Hendrick et al., 2009). The researchers defined clinical reasoning as "the thinking and decision making process used by practitioners" (p. 431). A sample of the student population from various years (only those enrolled in the physical therapy program) was selected to participate in a semi-structured, in-depth interview in the middle of the academic year while students were fully involved in their studies. Students were asked about their understanding of their practice and were encouraged to provide examples to illustrate their reasoning of particular clinical situations. Finally, they were also asked if they could elaborate on how they achieved such understandings. The data the researchers obtained suggested categories of students' conceptualizations in terms of:

Category A-applying knowledge and experience to the problem, patient, or situation; category $\mathrm{B}$ - analyzing and reanalyzing to deduce the problem and treatment; category $\mathrm{C}$-rationalizing or justifying what and why; category D—combining knowledge to reach a conclusion; and category E—problem solving and pattern building. (Hendrick et al., 2009, p. 434)

The results showed the influence of different theories towards the practice of physical therapy among the students as they progressed in their learning from year one to year four. There was also a developmental continuum that allowed students to build up a framework which included different approaches to their practice.

The study by Hendrick et al. (2009) describes the complexity of skills that physical therapists need to develop for their professional work. First of all, there has to be congruence between course programs and the abilities professors intend to elicit or teach to students. Second, there have to be constant moments of feedback among professors and students in order to assess students' clinical reasoning skills in their field of knowledge. Third, it seems that scenarios where students need to interact with either their professors or their peers are advantageous, as these reasoning skills grow as a result of the constant exchanges of more expert views such as those of the professor's or their classmates' ideas.

The common thread that runs through many of the studies on the teaching of EAP to university students seems to suggest that there has to be congruence between the program goals and objectives and the students' needs, particularly students' language needs that are for the most part oriented towards interacting with colleagues at the expert level and with patients at both the professional and personal level. Besides that, there is a clear need to design courses that tap into both the complexity of cognitive abilities and the language requirements to perform them. Furthermore, it is important to take into consideration the fact that students do not always have the same levels of language proficiency that are required for content-based courses; therefore, professors need to have in mind the language demands 
the course contents place on the students and act on them by building teaching sequences that involve all the students regardless of their language abilities.

The above conclusions point to the direction of some theoretical tenets that include ideas from second language acquisition, cooperative learning, and differentiated instruction. Each one of these elements provides the bases to stage the teaching of both content and language with ESL students of diverse linguistic abilities.

Kagan (1995) discusses the relationship between input, output, and context in second language acquisition through the framework of cooperative learning. He brings together Krashen's (1982) input hypotheses, Swain's (1985) insights about language output, and his own views concerning context in cooperative learning.

Kagan (1995) states that second language acquisition is fostered as long as input is "comprehensible, developmentally appropriate, redundant, and accurate" (p. 1). Students working in groups need to adjust language input according to the circumstances and their peers' levels of proficiency. In cooperative learning, the teacher is not always the source of input; many times students will be the source, so the moments of negotiation around language input allow students to advance in their levels of proficiency. When students experience a variety of activities in which they are exposed to input, this input will be redundant as part of communication exchanges that are meaningful for the circumstances of the cooperative work instead of a myriad of language drills that are intended to make the language redundant yet useless. However, teachers need to be cautious about the levels of accuracy in the cooperative learning mode since the source of input stems from many group members with various levels of language proficiency regarding aspects such as grammar, pronunciation, and intonation patterns. In order for teachers to resolve these possible problems, their cooperative work may to some extent compensate for the variety of language quality which may always be addressed by some explicit teaching or general feedback on particular language issues.

According to Kagan (1995), second language acquisition will also happen when there is output from individuals that is "functional or communicative, frequent, redundant, and identity congruent" (p. 2). Speech samples are functional or communicative if they are representative of what people use in their settings of occurrence. For this reason, the speech in cooperative learning is related to and relevant for the particular situations the groups are discussing. A variety of group configurations is very advantageous in order for learners to take part in class activities; for example, learners may work in pairs or groups of different sizes so that the chances for the group to hear what students have to say are greater. Students will benefit greatly in practicing and producing language that is akin to their identity. Conversely, students may experience feelings of alienation when they are asked to work on language activities that are extraneous to who they are or what they actually need the language for. 
Kagan (1995) points out several contextual considerations for the acquisition of a second language. He asserts that this will happen as long as the context is "supportive/motivating, communicative/referential, developmentally appropriate, and feedback rich" (p. 3). Cooperative work is usually about the here and now, so group members are constantly reminded of the purpose and the results of their efforts. In other words, the cooperative learning work is about "delivering the goods." Students tend to have a much safer environment for their participation as part of small groups rather than with the whole class.

Besides Kagan's (1995) discussion of theories of second language acquisition and cooperative learning, it is worth looking at the perspectives on teaching learners with diverse abilities. Differentiation is the deliberate effort of teachers to tailor their teaching according to their students' needs. Thus, differentiated instruction conceptualizes learners as they are and offers them possibilities to work their way forward (Gregory \& Chapman, 2007).

Gregory and Chapman (2007) state that differentiation instruction happens "at the level of content, assessment tools, performance tasks, and instructional strategies" (p. 3). There are several aspects regarding the differentiation of content which can occur by leveling materials, by providing a variety of these materials, and by providing students with choices. The differentiation of assessment tools has to do with the continuous assessment of students' progress that may even begin with the establishment of students' prior knowledge of the content intended to be studied. Regarding performance tasks, differentiation includes a variety of activities students may use to evidence their learning. Finally, differentiating instructional strategies aim to include students' learning styles and interests; sometimes an inventory of these styles may occur prior to or early in the beginning of a particular course.

One of the most important insights from differentiated instruction at the level of instructional strategies is the purposeful use of cooperative learning. Gregory and Chapman (2007) argue that differentiated instruction "accommodates academic diversity and heterogeneous grouping" (p. 87), which means that students with diverse abilities can be productive when they are part of flexible group dynamics in the classroom.

\section{Research Design}

This is an action-research study whose main purpose is to plan and implement changes in a particular teaching/learning context to improve practice and provide understanding for its stakeholders. The researchers decided to develop their classroom intervention with the following research questions in mind:

- How do language-building activities influence students' class participation in a Manual Therapy class for ESL learners? 
- To what extent do changes in teacher/student interaction (individual, pair, and group work) patterns promote class participation in an ESL course in Manual Therapy?

The researchers determined that their sources for data collection were the manual therapy professor's actions in terms of her lesson plans (Freeman, 1998). The professor's thoughts also played an important part as a source of data since she was always in touch with the students not only throughout class encounters but also through periodical teacher-student extra class tutoring sessions. The specific instrument to account for the professor's thoughts was her anecdotal records.

The research design also considered students' actions as they engaged in various class activities geared towards their class participation and content learning. The researchers used sociograms to record changes in students' participation based upon three specific class moments of interaction, namely, individual, pair, and group work. Finally, students provided the researchers with their own feedback on their class participation through some feedback cards they filled out and gave to the manual therapy professor at the end of each session.

\section{Research Participants and Class Format}

The Manual Therapy Introductory Course is an eight-class seminar (16 hours total) with a group of 24 students, 22 women and two men. This group had a different range of abilities and interests which were manifested when they took an initial language inventory survey. Students were asked about their preferences regarding their own learning as well as their perception on their language abilities in English. The purpose of the survey was to get an idea of the learners' strengths and weaknesses as well as their learning styles. The information gathered through this questionnaire supported the class design per session and the general lesson plan for the entire course; a variety of activities were introduced in different lessons according to what students had responded their preferences were regarding their ways to learn.

A number of students (10) reported they preferred kinesthetic learning strategies (role play, simple skit, or dramatization) or auditory strategies (6) such as interviews, audiotapes, speeches, debates, and group discussions. Very few reported their preference for either visual (3) or written type of learning (2), and the remaining students (3) reported no preference at all by showing very mixed results.

In regard to class work, 18 students reported that they liked working either individually, or in pairs or groups; only two reported that they preferred working in groups, and four reported their preference for individual work. Another result observed from this survey was their perception towards their performance in English: They felt they were good but they were shy or feared their peers' reaction if a mistake was made, or they had some trouble while speaking or limited capacity to respond to challenges due to their lack of vocabulary. 
This Manual Therapy Introductory Course takes into account one introductory lesson, five main lesson topics, one case study built-up and feedback class, and one final written evaluation session. The class sessions lasted two hours and were divided into two halves. In the first half of each session, students developed some language-building activities so that they had exposure to the language input required to learn the content. They also needed to experience this language input in communicative contexts that resembled actual professional practices; some of this input included language functions such as asking and writing questions, giving instructions, or following directions. In the second half, students worked on a variety of group configurations so that this language input was both redundant and recyclable throughout the lesson.

Table 1 illustrates the lesson plan designed by the professor in manual therapy for each one of the five sessions of the course. It includes the topics, the content, and the language-building activity. The choice of activities was based on the students' learning styles and preferences as they stated in the survey. For example, some claimed to prefer auditory rather than visual activities; others felt that they learned best by doing something instead of being told how to do it.

Table 1. Class Topics, Content, and Language-Building Activities

\begin{tabular}{|c|l|l|l||}
\hline $\begin{array}{c}\text { Session } \\
\text { Number }\end{array}$ & \multicolumn{1}{|c||}{ Topic } & \multicolumn{1}{c||}{ Content } & $\begin{array}{l}\text { Language-Building } \\
\text { Activity }\end{array}$ \\
\hline \multirow{2}{*}{1} & $\begin{array}{l}\text { Models in Manual } \\
\text { Therapy (MT) }\end{array}$ & $\begin{array}{l}\text { Describe common models in } \\
\text { Manual Therapy. }\end{array}$ & $\begin{array}{l}\text { Descriptive language } \\
\text { This model.../The key } \\
\text { features of this model } \\
\text { are... }\end{array}$ \\
\hline \multirow{2}{*}{3} & $\begin{array}{l}\text { Patient interview } \\
\text { model and subjective } \\
\text { evaluation in MT }\end{array}$ & $\begin{array}{l}\text { Interview patients following } \\
\text { the subjective evaluation } \\
\text { protocol. }\end{array}$ & $\begin{array}{l}\text { General information } \\
\text { questions and specific } \\
\text { wh-questions. }\end{array}$ \\
\hline $\begin{array}{l}\text { Objective evaluation: } \\
\text { Upper quarter, } \\
\text { generalities }\end{array}$ & $\begin{array}{l}\text { Therapist/Patient interaction } \\
\text { based on the upper quarter } \\
\text { muscle region. }\end{array}$ & $\begin{array}{l}\text { Role-play interview } \\
\text { based on } \\
\text { therapist/patient } \\
\text { interactions. }\end{array}$ \\
\hline
\end{tabular}


Language-Building Activities and Interaction Variations With Mixed-Ability ESL University Learners in a Content-Based Course

\begin{tabular}{|c|l|l|l||}
\hline $\begin{array}{c}\text { Session } \\
\text { Number }\end{array}$ & \multicolumn{1}{|c||}{ Topic } & Content & \multicolumn{1}{c||}{$\begin{array}{c}\text { Language-Building } \\
\text { Activity }\end{array}$} \\
\hline \multirow{2}{*}{5} & $\begin{array}{l}\text { Objective evaluation: } \\
\text { Lower quarter, } \\
\text { generalities }\end{array}$ & $\begin{array}{l}\text { Therapist/Patient interaction } \\
\text { based on the lower quarter } \\
\text { muscle region. }\end{array}$ & $\begin{array}{l}\text { Role-play interview } \\
\text { based on } \\
\text { therapist/patient } \\
\text { interactions. }\end{array}$ \\
\hline 5 & Muscle chains & $\begin{array}{l}\text { Identify and locate muscles } \\
\text { in muscle chains. }\end{array}$ & $\begin{array}{l}\text { Follow and give } \\
\text { directions on muscle } \\
\text { locations in specific } \\
\text { muscle chains. }\end{array}$ \\
\hline
\end{tabular}

An external observation of each class was conducted by the English professor whose role during the course sessions was to watch students' language interaction patterns in terms of individual, pair, and group work. These observations and the dynamics that resulted in the patterns of students' interactions were illustrated through some class sociograms. Additionally, the manual therapy professor had an anecdotal record that she considered important for the purposes of the research questions in the study. For example, she wrote about students' attempts to communicate despite their language proficiency; she also wrote about students' personal class notes or students' responses whenever she felt they were not prepared for the class or the activities. The manual therapy professor asked students to fill out a feedback card at the end of each session. Students had to register three aspects of the class contents: First, they had to write what they had learned in the session. Next, they had to write three key words for the day. Finally, they had to give themselves a grade on their participation in three class moments namely individual, pair, and group work.

\section{Results}

The above description of the research activities that intended to explore the levels of student participation in a course of Manual Therapy (with ESL mixed ability students at Universidad del Rosario in Colombia) provided us with some evidence to articulate some findings which we want to discuss keeping in mind the three research questions of the study.

\section{How Do Language-Building Activities Influence Students' Class Participation in a Manual Therapy Class for ESL Learners?}

In the first two lessons we found that students established the existence of some vocabulary and language patterns on technical aspects of Manual Therapy that helped them produce oral language in order to participate in the class activities. In the first session, 
students became aware of general language patterns to describe both concepts and models in Manual Therapy. For example, students were encouraged to describe these models by saying: "The ___ model __ talks about___, or "The key aspects of the ___ model are and they can be related to ___." Similarly, in the second session, the language-building activities were carried out around the formulation of questions when interviewing a patient. The manual therapy professor made sure students structured their questions properly by insisting on their avoiding translations. Two of these questions were: "What is the reason for your consultation? "How many years do you have?" Instead, they were guided to produce more appropriate questions such as: "How may I help you today?" "How old are you?"

In the third session, students performed role-plays of therapist/patient interviews which resembled the real exchanges of therapists in their practice. Thus, the communication situation matched the content of the professional service sought by patients on a daily basis. It is worth mentioning that at this point, students were concerned about how to ask proper questions that helped them gather valuable data to establish the patients' health conditions.

In the next session, students continued with the role-plays of the therapist/patient interaction. This time, however, the language use was aimed at getting students to display their reasoning skills by identifying a sequence of movements and questions to establish the physical manual therapy diagnosis. Once again, we can say that the language use was far beyond the manipulation of linguistic forms since what really mattered for students was to complete the task at hand; in the first place, it was to conduct an interview and in the second, to establish the physical condition of a patient based on the use of commands and instructions.

The last session helped students correlate the patient's evaluation outcome to a simple muscle chain analysis by using language patterns and new technical vocabulary. Consequently, the use of English was naturally promoted in contexts where these language patterns and vocabulary were relevant. Thus, we argue that language learning is the outcome of its own practice in communicative contexts.

When introducing this action research plan and differentiated students strategies to class, it is evident that working on a previous language-building activity improves the level of participation of students. On the completion of the feedback cards, we can observe how students grade their work better as each session goes by. We can also observe a better use of English structure to communicate their ideas either to the professor or to classmates.

One interesting case that the manual therapy professor considers worth pointing out in order to show how this language-building activity influenced participation is the following:

At the beginning of my very first session, one student approached me with a great concern of her future work in class because in her mind she considered herself very poorly suited for the language abilities required to perform in class. Her concern was not related to class contents but how to 
communicate her ideas and show that she could develop the skills for the successful completion of the course. She actually stated, in a quiet energetic way I must say, that she would not talk in class or write in English and if so she would only do it in a private moment to myself. Her first session turned out to be not as traumatic as she first thought according to my interview at the end of the class. (Anecdotal Record 1)

Two samples of this specific student's work are presented below. Her comments on the feedback card were written in Spanish. However, by the end of the second session and for the rest of the course, she participated with some written ideas in English which accounted for her learning. Figure 1 shows the student's attempt to work in both Spanish and English as she wrote down some of the key concepts they worked in the class session. In this card, the student seems to feel more at ease with key concepts in English.

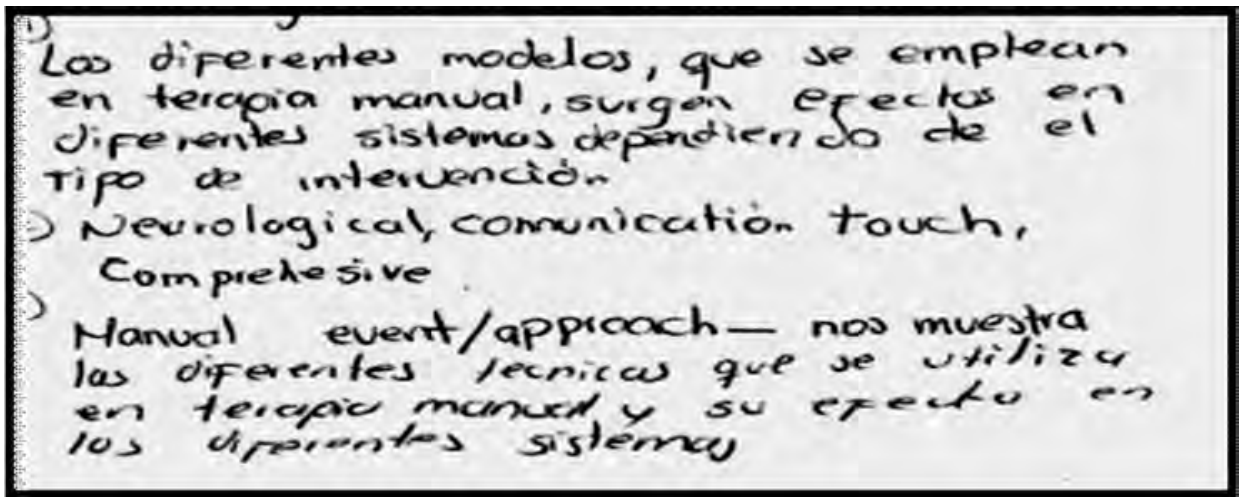

Figure 1. Feedback Card, Session 1

Figure 2 is a display of the student's attempt to pin down some key concepts, but this time she formulated her ideas entirely in English. This activity gained in complexity since students were integrating new concepts as the course progressed. As a result, they ended up writing complex sentences.

To What Extent Do Changes in Teacher/Student Interaction (individual, pair, and group work) Patterns Promote Class Participation in an ESL Course in Manual Therapy?

The answer to this question is based on the visual depictions and the researchers' reflections on the sociograms activity flow which were drawn in three moments of class, 


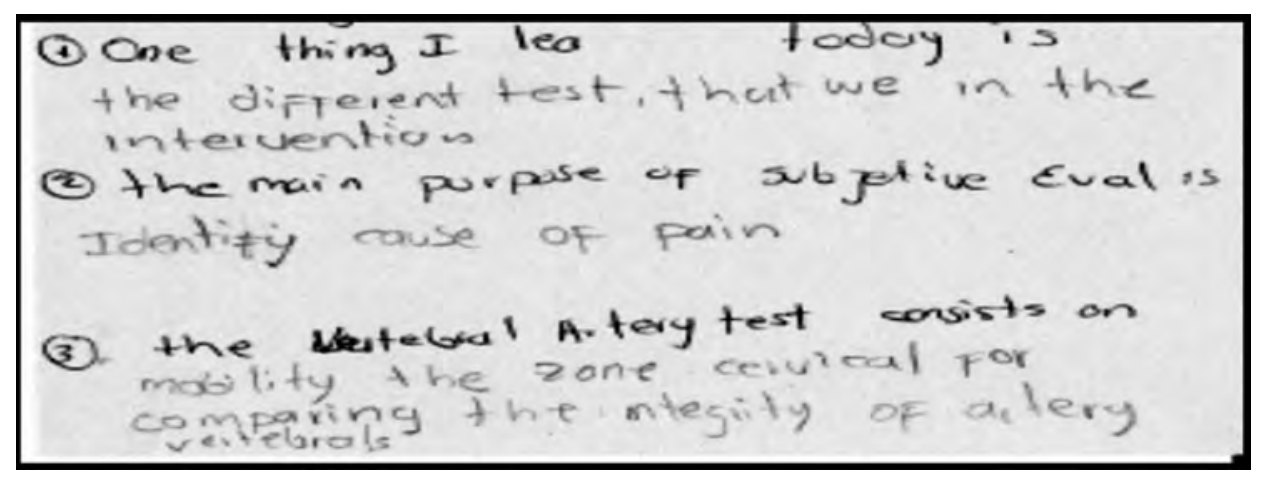

Figure 2. Feedback Card, Session 2

namely, individual, pair, and group work. Due to the scope of the present article, we provide evidence only for the students' individual and pair work activities.

Figure 3 shows that in Session 1 of the course students still felt they were part of the traditional teacher/student individual interaction around questions and answers from previously assigned class readings. Figure 3 also shows that in these initial stages students were more reliant on Spanish except for those who could express their ideas in English. Nevertheless, the professor encouraged students to contribute by reading their ideas in English despite problems in either grammar or pronunciation.

As the course developed, the sociograms began to display how students made the transition from the traditional roles they had had in class to a more participatory environment where they had to be concerned about their interactions with their peers (patients) in terms of activities they would normally carry out in their practice.

The individual work in Session 4 displayed, for instance, that there were more students participating only in English. We consider that this participation had to do with the fact that students were already familiar with the questions they had to ask their patients and because they had already reviewed their formulation in English. Furthermore, students were particularly interested in the relevance of their questions since they needed to respond to categories such as personal information, general data, regional vertebral, and obligatory information. This particular aspect is worth considering since the course aimed at developing both language and reasoning skills related to the therapists' professional practice. 
Language-Building Activities and Interaction Variations With Mixed-Ability ESL University Learners in a Content-Based Course

\begin{tabular}{|c|c|c|c|c|c|c|c|c|c|c|c|}
\hline \multicolumn{6}{|c|}{ Individual Work-Session 1} & \multicolumn{6}{|c|}{ Individual Work-Session 4} \\
\hline \multicolumn{6}{|c|}{$\begin{array}{l}\text { Number of students: } 24 \\
\text { Spelling activity: } \mathrm{S} \\
\text { Reading sentences: R } \\
\text { Interaction in either English or Spanish: } \underline{\mathbf{S} / \mathbf{R}} \\
\text { Number of students participating actively: } \underline{\mathbf{6}}\end{array}$} & \multicolumn{6}{|c|}{$\begin{array}{l}\text { Number of students: } 24 \\
\text { Review Questions: RQ } \\
\text { Interaction in English: } \underline{\mathbf{R Q}} \\
\text { Number of students participating actively: } \underline{\mathbf{1 0}}\end{array}$} \\
\hline $\begin{array}{c}\underline{1} \\
\underline{S} / \mathrm{R} \\
\end{array}$ & $\begin{array}{c}2 \\
S / R \\
\end{array}$ & $\begin{array}{c}3 \\
\mathrm{~S} / \mathrm{R} \\
\end{array}$ & $\begin{array}{c}4 \\
S / R \\
\end{array}$ & $\begin{array}{c}5 \\
\mathrm{~S} / \mathrm{R} \\
\end{array}$ & $\begin{array}{c}6 \\
S / R \\
\end{array}$ & $\begin{array}{c}\underline{1} \\
\underline{\mathrm{RQ}}\end{array}$ & $\begin{array}{c}2 \\
\mathrm{RQ}\end{array}$ & $\begin{array}{c}3 \\
\mathrm{RQ}\end{array}$ & $\begin{array}{c}\underline{4} \\
\underline{\mathrm{RQ}}\end{array}$ & $\begin{array}{c}5 \\
\mathrm{RQ}\end{array}$ & $\begin{array}{c}6 \\
\mathrm{RQ}\end{array}$ \\
\hline $\begin{array}{c}7 \\
\text { S/R }\end{array}$ & $\begin{array}{c}8 \\
\mathrm{~S} / \mathrm{R}\end{array}$ & $\begin{array}{c}9 \\
\mathrm{~S} / \mathrm{R}\end{array}$ & $\begin{array}{c}10 \\
\mathrm{~S} / \mathrm{R}\end{array}$ & $\underline{\underline{S} / R}$ & $\underline{\underline{12}} \underline{\mathrm{S} / \mathrm{R}}$ & $\begin{array}{c}7 \\
\text { RQ }\end{array}$ & $\begin{array}{c}8 \\
\mathrm{RQ}\end{array}$ & $\begin{array}{c}\underline{9} \\
\underline{\mathrm{RQ}} \\
\end{array}$ & $\begin{array}{c}10 \\
\mathrm{RQ}\end{array}$ & $\begin{array}{r}\underline{11} \\
\underline{\mathrm{RQ}}\end{array}$ & $\begin{array}{l}\underline{12} \\
\underline{\mathrm{RQ}}\end{array}$ \\
\hline$\underline{\underline{13}} \underline{\mathrm{S} / \mathrm{R}}$ & $\begin{array}{c}14 \\
S / R\end{array}$ & $\begin{array}{c}15 \\
S / R\end{array}$ & $\begin{array}{c}16 \\
S / R\end{array}$ & $\begin{array}{c}17 \\
S / R\end{array}$ & $\begin{array}{c}18 \\
S / R\end{array}$ & $\begin{array}{r}\underline{13} \\
\underline{\mathrm{RQ}}\end{array}$ & $\begin{array}{c}14 \\
\mathrm{RQ}\end{array}$ & $\begin{array}{c}15 \\
\mathrm{RQ}\end{array}$ & $\begin{array}{c}16 \\
\mathrm{RQ}\end{array}$ & $\underline{\underline{17}}$ & $\begin{array}{c}18 \\
\mathrm{RQ}\end{array}$ \\
\hline $\begin{array}{c}19 \\
S / R\end{array}$ & $\begin{array}{c}20 \\
S / R\end{array}$ & $\underline{21}$ & $\underline{\underline{22}} \underline{\mathrm{s} / \mathrm{R}}$ & $\begin{array}{c}23 \\
S / R\end{array}$ & $\begin{array}{c}24 \\
S / R\end{array}$ & $\begin{array}{c}19 \\
\text { RQ }\end{array}$ & $\begin{array}{c}20 \\
\text { RQ }\end{array}$ & $\begin{array}{r}\underline{21} \\
\underline{\mathrm{RQ}}\end{array}$ & $\begin{array}{r}\underline{22} \\
\underline{\mathrm{RQ}}\end{array}$ & $\begin{array}{c}23 \\
\mathrm{RQ}\end{array}$ & $\begin{array}{r}\underline{24} \\
\underline{\mathrm{RQ}}\end{array}$ \\
\hline
\end{tabular}

Figure 3. Class Participation Grid for Individual Work

A more uniform pattern of interaction appeared in Session 4. However, this time there was a more consistent use of English which did not depend exclusively on the professor's input. We can also notice that some students helped the professor keep the flow of English in class despite the fact that some students still interacted in Spanish. Nevertheless, students remained on task for the most part of the session. In fact, they all demonstrated their interest in figuring out the most appropriate ways to formulate their ideas about manual therapy models in terms of both content and language. Figure 4 shows the variations in pair work interaction in Session 1 and later in the course in Session 4.

Finally, Session 4 showed that the patterns of interaction were bilingual. Some students brought some materials such as dictionaries and English textbooks so that they could prepare their role-plays based on different tests on manual therapy. We consider that students brought resources since the task at hand demanded from them to be able to ask specific questions that would give relevant information of both the patients' personal and physical state. We also noticed that students kept working in both languages since they still needed to fully grasp some of the technical vocabulary for the assignment. 


\section{Pair Work-Session 1}

Number of students: 24

Spelling Activity: S

Reading sentences: $\mathrm{R}$

Language of interaction: English $=\mathbf{E n g}$, Spanish $=\mathbf{S p a}$

Number of students participating in the session: $\underline{24}$

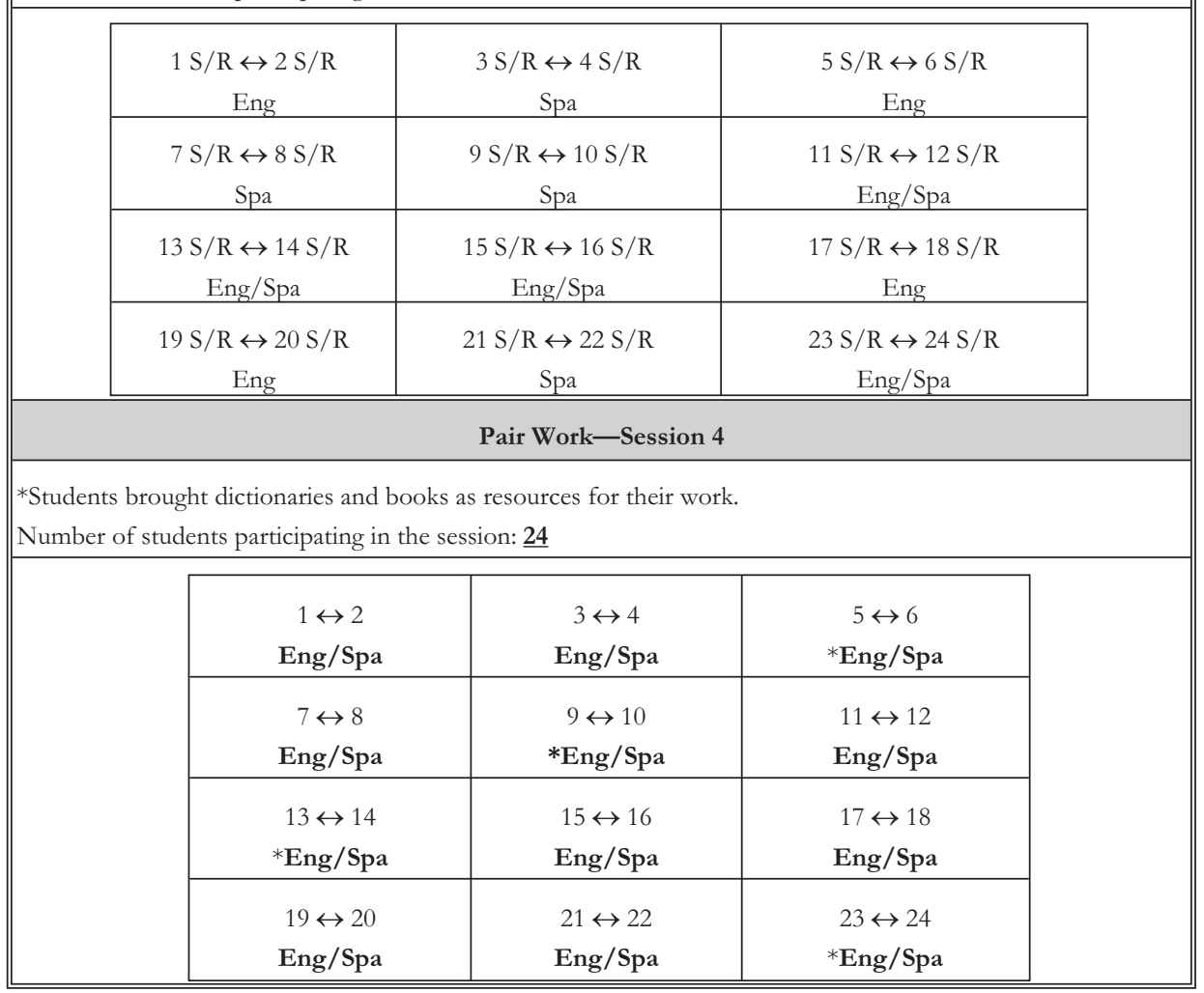

Figure 4. Class Participation Grid for Pair Work

We think it is very important to emphasize that students started to assume that English was natural to what they were doing in class. Even though some of them were still concerned about some language issues such as question formulation, they were more concerned about collecting the necessary information regarding their patients' health condition. 
With regard to the class patterns of interaction, namely, individual, pair, and group work, the sociograms showed how the level of teacher/student interaction and student/student interaction in English gradually increased. We think the fact that students were constantly exposed to the language input helped them assume both the class dynamics and the linguistic exchanges around interviews.

From most of the feedback cards gathered in this particular 24-student course, we can see that they graded the partner and group work better, and as professors we believe this trend is related to an increased self-confidence developed after five sessions and because students realized the role they needed to play in the class in order to build up their knowledge and participation. Also, they realized they could promote their language skills when sharing their ideas and work with peers who had the same concerns with their second language skills.

\section{Limitations}

Even though the action research study was for the most part oriented towards working with mixed-ability ESL learners, the university needs to consider some language courses that address the specific language needs of the students in the therapy programs in the early stages of their formation. This will allow them to be more prepared to face the demands of more advance courses later in their curriculum.

It is very difficult to help students advance in their learning both linguistically and academically in courses whose durations are too short. This limitation echoed some of the concerns of faculty in similar contexts as we pointed out earlier in the literature review. We feel that students require longer courses so that they can receive a greater exposure to the language and content of the courses.

\section{Conclusions}

This action research project with a mixed-ability group of ESL learners in the Therapy Program at Universidad del Rosario shows that it is possible to have a course with students of different language abilities and still cater to both their linguistic and cognitive needs regarding their area of studies. However, university professors involved in such a project must pay special attention to the language needs students have in order to cope with the demands of a course. Moreover, professors who are interested in using English as a medium of instruction need to redefine and/or adjust their teaching styles so that students meet their demands both cognitively and linguistically. It is important for these professors to acknowledge the fact that students working in a second/foreign language have challenges that they would not normally face when studying in their first language. 
The critical event that motivated this study had to do with the manual therapy professor's concerns regarding her students' class participation and interaction in previous manual therapy courses taught in English. In this regard, the study shows that class participation and interaction can be built up if professors plan their courses, taking into consideration the language demands that their content poses on students and deliberately developing activities to meet such demands in terms of both content and language.

Professors working with mixed-ability language students also need to pay special attention to their class dynamics since it is fundamental to guarantee some fair level of participation for all the parties involved — namely, the range of students' language abilities from basic to advance. Besides that, giving students different opportunities to work with the language input in a variety of class configurations from individual to pair and group work increases the level of class participation.

It is also the professor's responsibility to make the match between the language and content activities so that students feel that they have to master the language component that is required in order to understand and learn the class contents. It could be a matter of isolating the language functions and forms students would certainly need to communicate successfully in particular contexts.

It is worth highlighting that this research process helped students to realize that they did not need to have advanced oral abilities in English to be able to participate in the course; however, they needed to understand that there were specific language functions and forms required to conduct professional interviews and patients' evaluations. This is perhaps one of the most interesting findings of the present study; the content professor matched both the language and content required for students to advance in their clinical reasoning skills that were fundamental for their professional performance.

This research also demonstrated that the concept of class participation may take a variety of forms which gave the class members opportunities to participate flexibly, that is, students could answer the professor's questions, make comments, and even reflect on their own language mistakes. All of these communicative exchanges do reflect class participation.

Students' class participation and learning were increased by providing them languagebuilding activities and varieties of formats for classroom interaction that ranged from individual, pair, and group work.

\section{References}

Andrade, M. S. (2010). Increasing accountability: Faculty perspectives on the English language competence of nonnative English speakers. Journal of Studies in International Education, 14(3), 221-239. 
Bean, J. C., \& Peterson, D. (1998). Grading classroom participation. New Directions for Teaching and Learning, 74(1), 33-40.

Freeman, D. (1998). Doing teacher research: From inquiry to understanding. New York, NY: Heinle \& Heinle Publishers.

Gregory, G. H., \& Chapman, C. M. (2007). Differentiated instructional strategies: One size doesn't fit all. Thousand Oaks, CA: Corwin Press.

Hendrick, P., Bond, C., Duncan, E., \& Hale, L. (2009). Clinical reasoning in musculoskeletal practice: Students' conceptualizations. Physical Therapy, 89(5), 430-442.

Kagan, S. (1995). We can talk: Cooperative learning in the elementary ESL classroom. CAL Digest. Retrieved from http://www.cal.org/resources/digest/kagan001.html

Krashen, S. D. (1982). Principles and practices in second language acquisition. Oxford, UK: Pergamon.

Liu, J. Y., Chang, Y. J., Yang, F. Y., \& Sun, Y. C. (2011). Is what I need what I want? Reconceptualising college students' needs in English courses for general and specific/academic purposes. Journal of English for Academic Purposes, 10(4), 271-280.

Swain, M. (1985). Communicative competence: Some roles of comprehensible input in its development. In S. M. Gass \& C. G. Madden (Eds.), Input in second language acquisition (pp. 235-253). Rowley, MA: Newbury House.

Universidad del Rosario, School of Medicine and Health Sciences. (2011). Working papers on academic mobility. Bogotá, CO: Author.

\section{The Authors}

Héctor Manuel Serna Dimas, $\mathrm{PhD}$, is the research group director in Linguistics, Translation, and Organizational Communication in the School of Humanities and Social Sciences at Universidad EAN, Colombia.

Erika Ruíz Castellanos, P.T., is a faculty member in the Rehabilitation Programs in the School of Medicine and Health Sciences at Universidad del Rosario, Colombia. 